
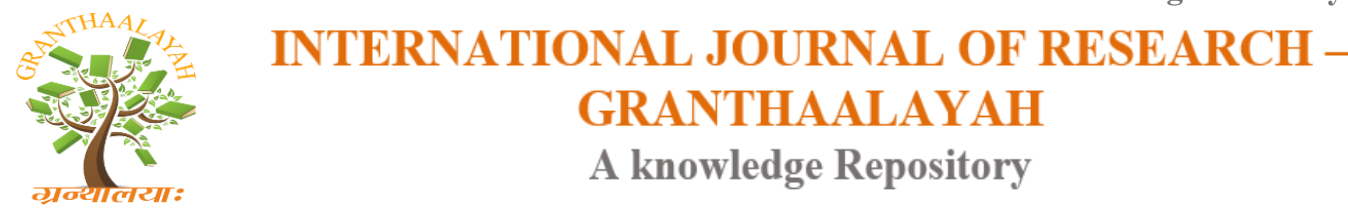

Science

\title{
HAEMATOLOGICAL PARAMETERS AMONG SUDANESE PATIENTS WITH CHRONIC RENAL FAILURE
}

\author{
Raian Bakhet Yassein ${ }^{1}$, Nada Omer Alseedig ${ }^{2}$, Siham Khalifa Abd Allah ${ }^{3}$, \\ Areeg Alsail Mohmmed ${ }^{4}$, Nosiba Abdelmajid Alballah ${ }^{5}$, Mohamed Abedelrahman Syid ${ }^{6}$ \\ ${ }^{1}$ Haematology Department, Faculty of Medical Laboratory Sciences, Shendi University, SUDAN \\ 2, 3, 4, 5 Haematology Department, Faculty of Medical Laboratory Sciences, Shendi University, \\ SUDAN \\ ${ }^{6}$ Haematology Department, Faculty of Medical Laboratory Sciences, Shendi University, \\ Lecturer, SUDAN
}

\begin{abstract}
Chronic renal failure is one of the more common causes of morbidity and mortality among Sudanese. This study describes altered haemoglobin concentration (Hb), haematochrit percent (Hct), red blood cells count (RBCs), platelet count (Plts) and white blood cells count (WBCs) in patients with chronic renal failure and describes the effect of disease duration on haemoglobin concentration and red blood cells count. Methods: Haematological parameters in (50) patients with Chronic renal failure and (50) age and sex matched controls were evaluated, living in Shendi locality in northern Sudan.

The results of this study showed that mean of $\mathrm{Hb}$ concentration, RBCs count, Hct percent and platelet count were exhibited significant decreased, but mean of WBCs count was insignificantly increased. Increased duration of the disease lead to significantly decreased on mean of $\mathrm{Hb}$ concentration and RBCs count.

Chronic renal failure is associated with different degrees of reduced haematological parameters. Also increase duration of the disease lead to significantly decrease in mean of $\mathrm{Hb}$ concentration and RBCs count.
\end{abstract}

Keywords:

Chronic renal failure, Haematological parameters, Sudan.

Cite This Article: Raian Bakhet Yassein, Nada Omer Alseedig, Siham Khalifa Abd Allah, Areeg Alsail Mohmmed, Nosiba Abdelmajid Alballah, and Mohamed Abedelrahman Syid, "HAEMATOLOGICAL PARAMETERS AMONG SUDANESE PATIENTS WITH CHRONIC RENAL FAILURE" International Journal of Research - Granthaalayah, Vol. 4, No. 1 (2016): 50-54. 


\section{INTRODUCTION}

Renal failure is a medical condition in which the kidney fails to adequately filter waste product from blood ${ }^{[1]}$.

Normal renal function is very important for homeostasis, so much so, that situations in which renal functions are impaired can be life threatening. Diseases of the kidneys are among the most important causes of death and disability in many countries throughout the world ${ }^{[2]}$.

The National Kidney Foundation in India states that, kidney diseases rank 3rd amongst life threatening disease, after cancer and heart disease. About $(200,000)$ persons go in to terminal kidney failure every year. Million more suffer from lesser forms of kidney disease ${ }^{[3]}$.

In United States $(35,000)$ deaths are attributed yearly to renal diseases. The rate of kidney disease mortality in the United States has increased by (52\%) in the past 16 years and continues to be higher in blacks than whites ${ }^{[4]}$.

Morbidity however is by no means insignificant. Millions of persons are affected annually by non-fatal kidney diseases, most notably infections of the kidney or lower urinary tract, kidney stones and urinary obstruction. Twenty percent of all women suffer from infection of the urinary tract of kidney at some time in their lives and at least (1\%) of the U.S. population develops renal stones ${ }^{[5]}$.

Renal diseases are associated with a variety of haemopoietic changes. Anemia parallels the degree of renal impairment and its most important cause is failure of renal erythropoietin secretion. Other factors include chronic blood loss, hemolysis and bone marrow suppression by retained uremic factors ${ }^{[6]}$.

\section{MATERIALS AND METHODS}

This is a cross-sectional descriptive study based on laboratory data of (50) patients with chronic renal failure hospitalized in Elmak neimer hospital university in Shendi locality and compared with (50) age and sex matched controls. The investigations were performed on venous blood sample drawn into EDTA tubes. Hematological parameters like Red Blood Cell count (RBC), Haemoglobin concentration (Hb), Packed cell volume (PCV), Platelet count (PLT) and White blood cell count (WBC) were estimated by using using Mindray haematology analyzer (Mindray bc-3000).

\section{RESULTS}

The data were analyzed with Statistical Package for Social sciences (SPSS-s) for windowsversion (20). The means of haematological values between renal failure patients and controls were compared, and in all statistical analysis, only P.value $<0.05$ were considered significant. 
Table 1: Show the mean of $\mathrm{Hb}$ concentration (renal failure patients/control):

\begin{tabular}{|l|l|l|l|}
\hline & Number & Mean \pm SD $(\mathrm{g} / \mathrm{dl})$ & P.value \\
\cline { 1 - 2 } Renal failure patients & 50 & $8.3 \pm 2.1$ & 0.000 \\
\cline { 1 - 2 } Control & 50 & $12.2 \pm 0.95$ & \\
\hline
\end{tabular}

$\mathrm{N}=100$

P.value is 0.000 that mean the result is significant.

Table 2: Show mean of RBCs count (renal failure patients/control):

\begin{tabular}{|l|l|l|l|}
\hline & Number & Mean \pm SD $\left(x 10^{12} / \mathrm{L}\right)$ & P.value \\
\hline Renal failure patients & 50 & $3.4 \pm 0.94$ & 0.000 \\
\cline { 1 - 2 } Control & 50 & $4.7 \pm 0.34$ & \\
\hline
\end{tabular}

$\mathrm{N}=100$

P.value is 0.000 that mean the result is significant.

Table 3: Show the mean of Hct (renal failure patients/ control):

\begin{tabular}{|l|l|l|l|}
\hline & Number & Mean \pm SD $(\%)$ & P.value \\
\hline Renal failure patients & 50 & $28.1 \pm 2.4$ & 0.000 \\
\cline { 1 - 2 } Control & 50 & $41 \pm 2.3$ & \\
\hline
\end{tabular}

$\mathrm{N}=100$

P.value is 0.000 that mean the result is significant.

Table 4: Show the mean of platelet count (renal failure patients/control):

\begin{tabular}{|l|l|l|l|}
\hline & Number & Mean \pm SD $\left(x 10^{9} / \mathrm{L}\right)$ & P.value \\
\hline Renal failure patients & 50 & $211 \pm 72.7$ & 0.03 \\
\hline Control & 50 & $263 \pm 65.4$ & \\
\hline
\end{tabular}

$\mathrm{N}=100$

P.value is 0.03 that mean the result is significant.

Table 5: Show the mean of TWBCs count (renal failure patients/control):

\begin{tabular}{|l|l|l|l|}
\hline & Number & Mean \pm SD $\left(x 10^{9} / \mathrm{L}\right)$ & P.value \\
\hline Renal failure patients & 50 & $6.0 \pm 2.1$ & 0.6 \\
\cline { 1 - 2 } Control & 50 & $5.8 \pm 1.5$ & \\
\hline $\mathrm{N}=100$ & &
\end{tabular}

P.value is 0.6 that mean the result is insignificant. 
Table 6: Show effect of duration of renal failure in mean $\mathrm{Hb}$ concentration:

\begin{tabular}{|l|l|l|l|l|}
\hline Duration & Frequency & Percentage & Mean $(\mathrm{g} / \mathrm{dl})$ & P.value \\
\hline $1-2$ years & 25 & 50 & 9.5 & 0.000 \\
\hline 3-4 years & 13 & 26 & 7.6 & \\
\cline { 1 - 4 } $\begin{array}{l}\text { More than 4 } \\
\text { years }\end{array}$ & 12 & 24 & 6.2 & \\
\hline Total & 50 & $100 \%$ & & \\
\hline
\end{tabular}

P.value is 0.000 that mean the result is significant.

Table 7: Show effect of duration of renal failure in mean RBCs count:

\begin{tabular}{|l|l|l|l|l|}
\hline Duration & Frequency & Percentage & Mean $\left(\mathrm{x} 10^{12} / \mathrm{L}\right)$ & P.value \\
\hline 1-2 years & 25 & 50 & 3.9 & 0.000 \\
\hline 3-4 years & 13 & 26 & 2.9 & \\
\hline $\begin{array}{l}\text { More than } \\
\text { years }\end{array}$ & 12 & 24 & 2.6 & \\
\hline \begin{tabular}{l} 
Total \\
\hline
\end{tabular} & 50 & $100 \%$ & & \\
\hline
\end{tabular}

P.value is 0.000 that mean the result is significant.

\section{DISCUSSION}

This study was conducted to study the complete blood count in renal failure patients. In our study, it has been observed that the Hb concentration (Table-1), RBCs count (Table-2) and Hct percent (Table-3) were decreased in chronic renal failure patients when compared with control. (P.value $<0.0001$, highly significant). This findings is in agreement with study obtained by other authors $^{[7]}$. The essential cause of decrease RBC counts which consequently decrease the $\mathrm{Hb}$ concentration and packed cell volume in chronic renal failure is impaired erythropoietin production and other factors which suppress marrow erythropoiesis and shortened red cell survival.

In the present study the platelet count was decreased (Table-4) among chronic renal failure patients (P.value < 0.03, significant). Erythropoietin potentites the effect of megakaryocyte colony stimulating factors, acetlyhydroase (PAF-AH) and paraoxonase (PON1). In chronic renal disease, impaired erythropoietin secretion leads to a decrease in platelet count ${ }^{[8]}$. The detection of receptors for erythropoietin in megakaryocytes is understandable, because erythropoietin levels can affect platelet level and because of extensive homology between erythropoietin and thrombopoietin, erythropoietin act as the major humoral regulator of platelet mass. 
This study show that there was insignificant increased in the mean of TWBCs count (Table-5) when compared with control. (P.value $=0.6$, insignificant). This study in agreement with study done in india ${ }^{[7]}$.

In our study, it has been observed that the duration of chronic renal failure affect on the mean of $\mathrm{Hb}$ concentration (Table-6) and mean of RBCs count (Table-7) by decreasing it significantly (P.value<0.0001, highly significant).

\section{CONCLUSION}

In conclusion, $\mathrm{Hb}$ concentration, $\mathrm{RBCs}$ count, Hct percent and Plts count were significantly decreased in sudanese patients with chronic renal failure, but WBCs count was insignificantly increased. Also increase duration of the disease lead to significantly decrease in $\mathrm{Hb}$ concentration and RBCs count among chronic renal failure patients.

\section{REFERENCES}

[1] Safa EZ.Aldeen Almukhtar,Kais Hassan Abdo ,Nabil Salman .Iron status In patients with chronic renal failure on hemodialysis. VOL5NO3.2006

[2] R.L.Bijlani. Apllied renal physiology. In: Understanding medical physiology. Third edition. JP Brothers, New Delhi. 2004; 8.4: 522-23.

[3] National Kidney Foundation: K/DOQI Clinical Practice Guidelines for Anemia of Chronic Kidney Disease. Am J Kidney Dis. 2006;47 (Suppl 3): S33-S53.

[4] Yael Waknine. Kidney disease mortality rates continue to increase. Medscape Medical News,Morbidity and Mortality Weekly report. March 16,2007.

[5] Charles E. Alpers. The Kidney. In: Vinay Kumar, Abul K. Abbas and Nelson Fausto. Robbins "pathologic basis of disease", Seventh edition, Elsevier Inc: 2004; 20: 960-65.

[6] Dodds A. Nicholls M. Haematological aspects of renal disease. Pub Med - index for medline. 1983; 11(4): 361-68.

[7] Suresh M, Mallikarjuna reddy N, Sharan B Singh M, Hari Krishna Bandi,Shravya keerthi G, Chandrasekhar M. Hematological Changes in Chronic Renal Failure. International Journal of Scientific and Research Publications, Volume 2, Issue 9, September 2012.

[8] Ch. Gouva, E. Papavasiliou, K.P. Katopodis, A.P. Tambaki, D. Christidis and A.D. Tselepis. Effect of Erythropoietin on Serum paf-acetylhydrolase in patients with Chronic Renal Failure. Nephrology dialysis transplantation 2006: 21(5):1270-77. 